\title{
Reproductive biology and quantity evaluation of the Black-striped pipefish Syngnathus abaster (Eichwald, 1831) in the Zaporozhian Reservoir
}

\author{
Fedonenko Olena ${ }^{1}$, Marenkov Oleg ${ }^{1}$, Stromenko Anna ${ }^{1}$, Kolesnik Natalia ${ }^{2}$
}

Oles Honchar Dnipropetrovsk National University, Ukraine

${ }^{1}$ Faculty of Biology, Ecology and Medicine, Department of General Biology and Water

Bioresources

P.M.B. 49050, Dnipropetrovsk, Ukraine

${ }^{2}$ Institute of Fisheries of NAAS of Ukraine

P.M.B. 03164, Kiev-164, Ukraine,

Corresponding Email: gidrobions@gmail.com

\begin{abstract}
Keywords: pipefish, reproduction, abundance and biomass, Syngnathus abaster, Zaporozhian
\end{abstract} Reservoir.

\begin{abstract}
The article presents the results of biology and ecology studies about the black-striped pipefish Syngnathus abaster (Eichwald, 1831) in the Zaporozhian Reservoir. Quantity and biomass of fish fingerlings and yearlings in different parts of the reservoir was determined. For the first time the reproductive indicators of pipefish in Zaporozhian Reservoir were investigated: the timing of spawning, fish fertility analysis, information on the number of embryos in the brood chamber of males were shown.
\end{abstract}

\section{INTRODUCTION}

Fish community living in shallow areas of water bodies, are an important component of aquatic ecosystems. Throughout the growing season pond littoral is a place of concentration small fish species with short life cycle. They use the coastal area for breeding, feeding and as s habitat [1]. These fish have small size, fast tempo of puberty, the ability to reproduce several times per season, and also caring about posterity - all of the above allows them to increase their quantity and biomass. Black-striped pipefish Syngnathus abaster (Eichwald, 1831) is a typical representative of the fish communities with a short life cycle $[2 ; 3]$.

Black-striped pipefish - is an euryhaline species of fish that can tolerate significant fluctuations in salinity, live in both fresh and salty water [4]. Pipefish live among vegetation in shallow waters of the Mediterranean, the Black, Azov and Caspian seas, enter rivers and lakes associated with them [5-7]. Analysis of published data shows that the research of the life cycle and reproduction of pipefish is small enough [7-10].

Earlier in the Ukraine this species was met only in the lower reaches of the Dnieper, the Black and Azov seas, and after the regulation of the Dnieper River and the creation of reservoirs cascade pipefish has become a typical inhabitant of the Dnieper reservoirs. Today, black-striped pipefish is a common and numerous species in Zaporozhian Reservoir. It is found throughout the coastal zone of the reservoir and its tributaries. Pipefish does not have commercial value and it is not used by amateur fishing. This species is a competitor for commercial planktophage fish.

Up to nowadays, there was no any comprehensive work about ecology and biology of black-striped pipefish in the Zaporozhian Reservoir [11].

\section{MATERIALS AND METHODS}

The subject of research was black-striped pipefish of Zaporozhian Reservoir. The material for the work was the individuals caught in the littoral areas of Zaporozhian Reservoir at depths ranging from $10 \mathrm{~cm}$ to $1.5 \mathrm{~m}$. Fish were being caught from the third decade of May till the first decade of August in the shallow waters in the standard breakpoints. Material was being collected 
during the growing season since 2010 to 2014 year. Catches of black-striped pipefish was carried out using fine-mesh seine (step of mesh $0.5 \mathrm{~mm}$, length $25 \mathrm{~m}$, height $1.5 \mathrm{~m}$ ) and ten-meter nylon fingerling scraper with a mesh size of $4 \mathrm{~mm}$.

All catches of young fish were sorted by type and counted, and length measurements were made with an accuracy of $1 \mathrm{~mm}$, the mass of individuals up to $0.01 \mathrm{~g}$. Biological analysis of fish was carried out according to the standard classical ichthyological methods [12-14]. The relative quantity of the pipefish was taken as a number of fish per $100 \mathrm{~m}^{2}$ of fishing area.

\section{RESULTS AND DISCUSSION}

In Zaporozhian Reservoir pipefish is widespread, it lives both in the open part of the reservoir, and in the thickets of aquatic plants. Species extended his range and settled in the small rivers of the reservoir watershed: Mokra Sura, Samara, Orel. At the beginning of 2000 in the river Mokra Sura this species were not met, but in recent years, pipefish is a typical species of the coastal areas of the river. Also pipefish spread to closed aquatic ecosystems of Dnipropetrovsk region flooded quarries, lakes and ponds. The spread of pipefish is contributed by flooding, the human factor and the birds, which can carry aquatic vegetation with the larvae and pipefish fry in other waters, where they adapt and increases their quantity.

This species does not form large crowds, and it is found in groups of 10-15 individuals. It moves slowly by the frequent and active movement of the pectoral fins and undulating movements of dorsal fin. These fish are almost inconspicuous in the backdrop of vegetation because of their color. In the thickets of aquatic plants this fish often stands at the bottom in the vertical half-bent position, the tail may rest on the ground. It is often found in this position while hunting small crustaceans. When the fish notices the food object (Daphnia, Cyclops) it attacks it with a sharp jerk and captures it with the help of an elongated cylindrical mouth in the form of a tube. Pipefish is a planktophage, it feeds on small crustaceans, chironomid larvae, fish eggs and larvae [7; 15]. In Zaporozhian Reservoir following feed components are marked in the spectrum of the nutrition of black-striped pipefish: rotifers (Bosmina sp., Chydorus sp.), small planktonic crustaceans (Daphnia sp., Cyclops sp., Chydorus sp.), cianobacterium (Cyanophyta) and detritus.

Studies of pipefish reproduction were not previously held in Zaporozhian Reservoir watershed. Special distinction between the terms of spawning and incubation in the Dnipropetrovsk region waters were not identified. Reproduction of pipefish in Zaporozhian Reservoir passes from the second half of May to August, massively - in June. We observed that the spawning of blackstriped pipefish takes place at a water temperature $18,0-22,0{ }^{\circ} \mathrm{C}$ in the coastal part of the reservoir at a depth of 0.4 to $1.3 \mathrm{~m}$. Females with mature eggs and the males with filled brood chamber or embryos were observed exactly in June.

Most males and females reach sexual maturity in the second year of life. Spawning of females is batched - eggs are laid in several portions, the male takes care of the offspring. It was found that the male pipefish is hatching eggs from several females (Fig. 1).

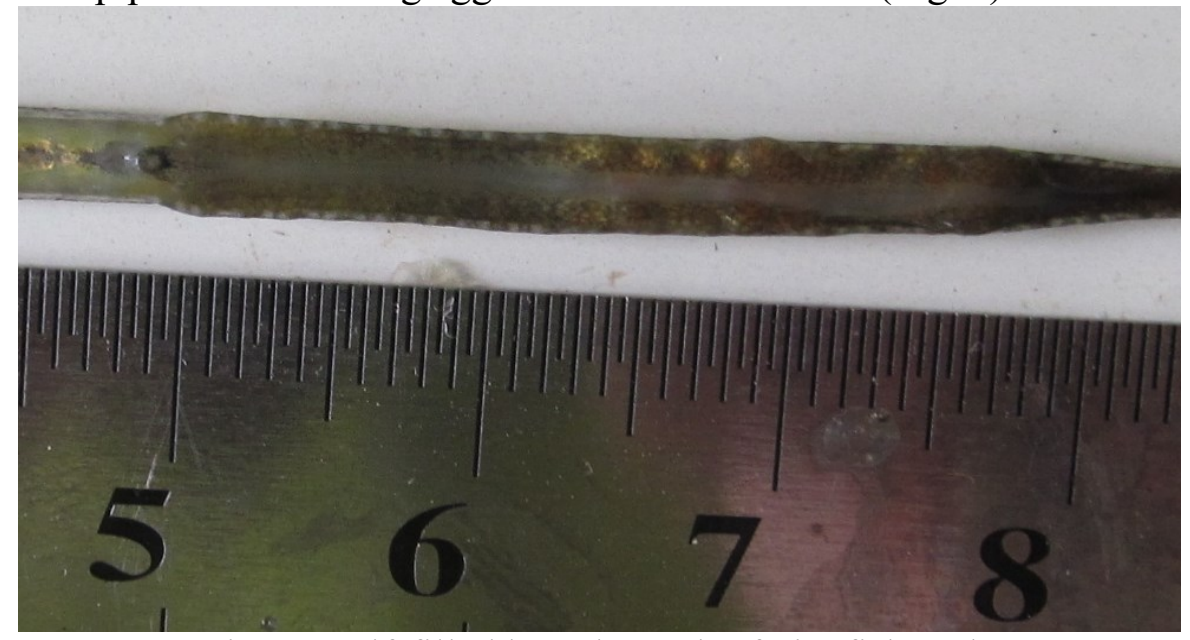

Fig. 1. Half-filled brood pouch of pipefish male 
Brood chamber of the male length 120-149 mm contains in average of 54 (range 41 to 66) eggs [16]. After female lays her eggs in the male's brood chamber, the camera shutters grow together, the fertilized eggs become completely isolated from the external environment (Fig. 2).

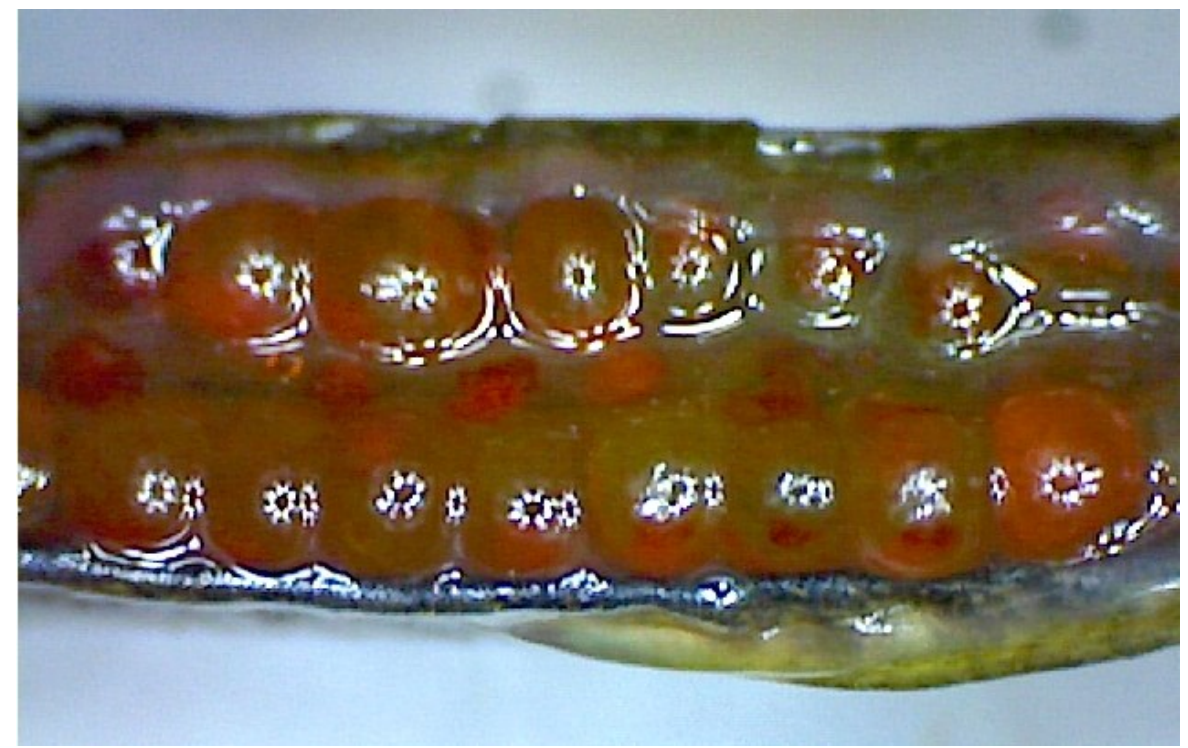

Fig. 2. Eggs of pipefish in the male brood chamber on the third day after spawning

Pipefish with body length between 9 and $12 \mathrm{~cm}$ had gonad which mass was about $0,13 \pm 0,01 \mathrm{~g}$, and the number of eggs ranged from 26 to 65 pieces. Maximum fertility had the female $150 \mathrm{~mm}$ long and it reached - 65 eggs. Measurements of eggs reached about 1,2 $\pm 0,05 \mathrm{~mm}$. Pipefish eggs have a bright orange color, have a considerable supply of nutrients and a large oil drop, which is located on the periphery of the egg (Fig. 3). Fertilized eggs in the male's brood pouch were very different in shape because of the degree of compression in the brood pouch, but in most cases they were almost spherical. Measurements of eggs on the third day after spawning reached $1,4 \pm 0,24 \mathrm{~mm}$.

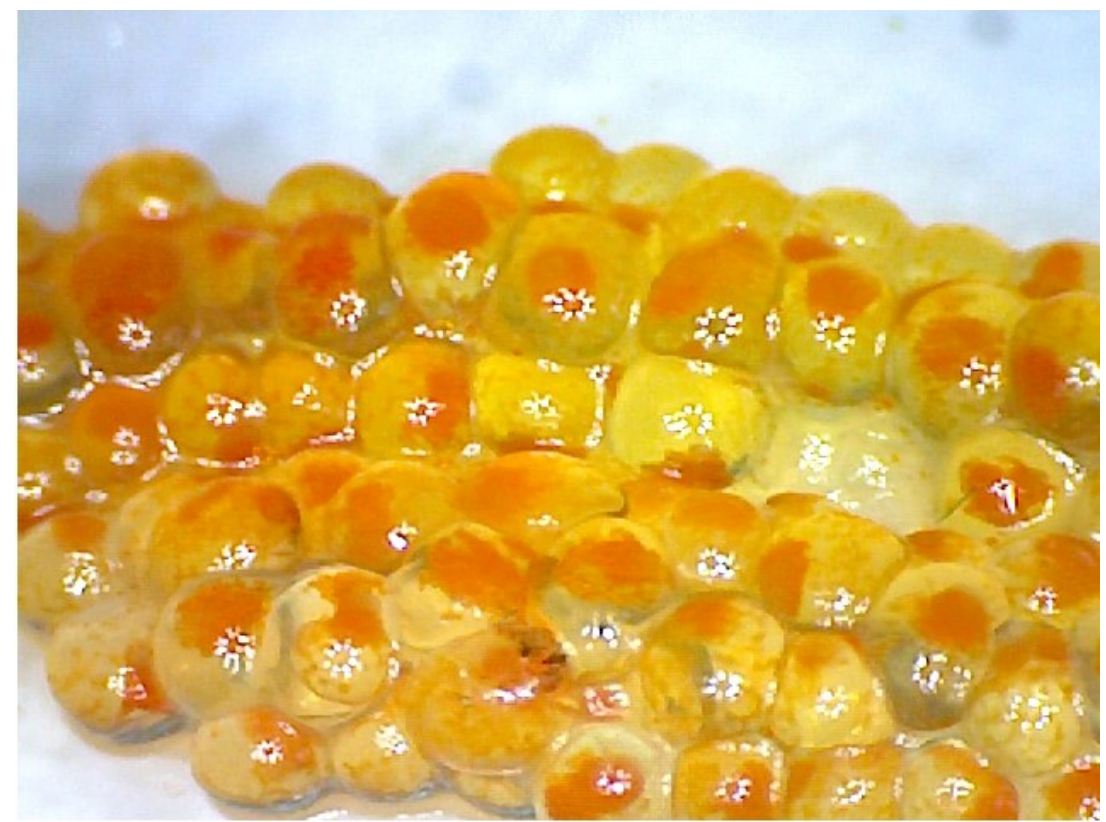

Fig. 3. Eggs of pipefish from the Zaporozhian Reservoir

In mid-June, we have caught males with formed embryos (Fig. 4). The approximate age of the embryos was 21 days [17]. The number of free embryos in the brood chamber of males ranged from 35 to 72 pieces. It was found that the whitebaits that leave the brood pouch have $1-1.5 \mathrm{~mm}$ long and have a fully formed fins. 


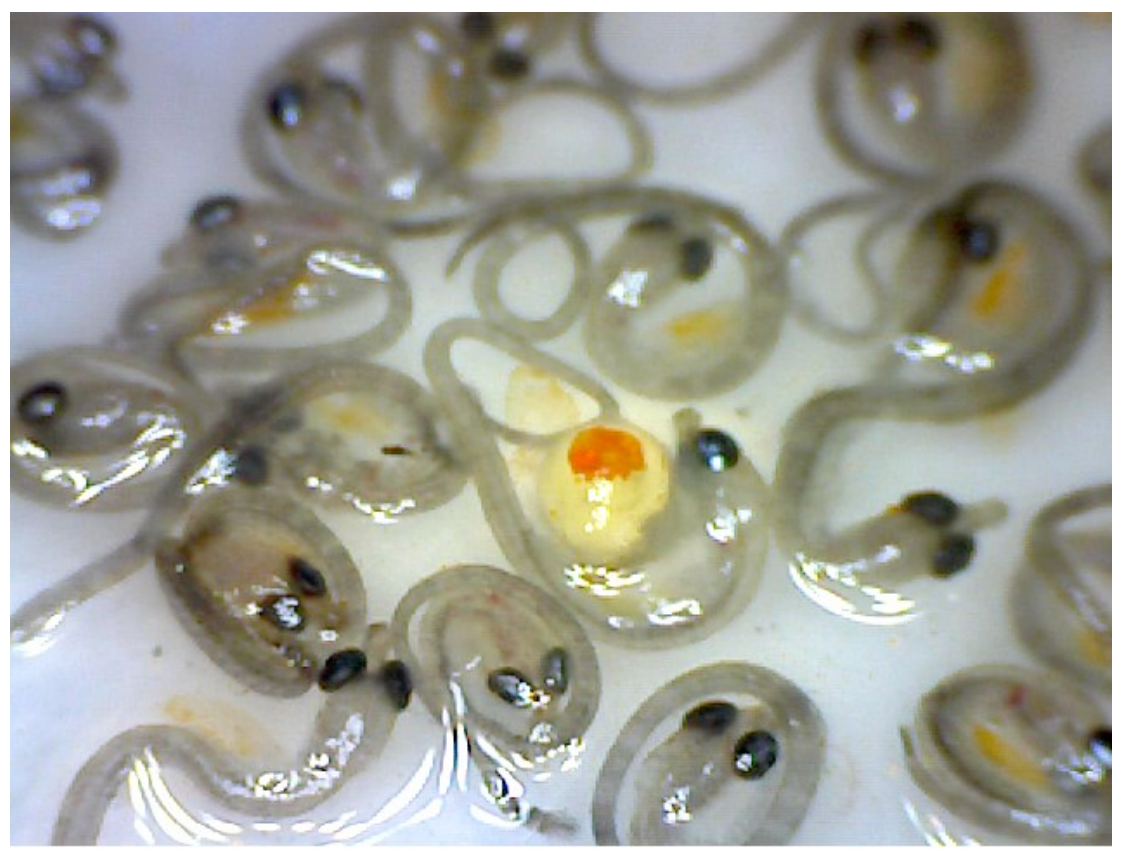

Fig. 5. General view of the pipefish embryos in age of 22 days, removed from the male brood chamber

Researches of 2010-2014, showed that the greatest quantity of pipefish in the Zaporozhian Reservoir was recorded in 2012 and amounted 5.28 ind./100 $\mathrm{m}^{2}$ of shallow reservoir areas. Biomass of pipefish fingerlings ranged from $0.28 \mathrm{~g} / 100 \mathrm{~m}^{2}$ (index 2013) to $4.38 \mathrm{~g} / 100 \mathrm{~m}^{2}$ (index 2012). The average annual quantity and biomass of pipefish fingerlings in the Zaporozhian Reservoir reached $2.77 \mathrm{ind} . / 100 \mathrm{~m}^{2}$ and $1.82 \mathrm{~g} / 100 \mathrm{~m}^{2}$, respectively (Table 1).

Table 1. Quantity and biomass of S. nigrolineatus in Zaporozhian Reservoir, 2010-2014.

\begin{tabular}{|c|c|c|c|c|c|c|c|c|}
\hline \multirow{2}{*}{ Years } & \multicolumn{4}{|c|}{ Samara Bay } & \multicolumn{3}{c|}{ Zaporozhian Reservoir } \\
\cline { 2 - 10 } & \multicolumn{2}{|c|}{$0+$} & \multicolumn{2}{c|}{$1+$} & \multicolumn{2}{c|}{$0+$} & \multicolumn{2}{c|}{$1+$} \\
\cline { 2 - 10 } & $\mathrm{x}$ & $\mathrm{y}$ & $\mathrm{x}$ & $\mathrm{y}$ & $\mathrm{x}$ & $\mathrm{y}$ & $\mathrm{x}$ & $\mathrm{y}$ \\
\hline 2010 & 1,23 & 0,66 & 1,65 & 1,81 & 2,44 & 1,17 & 2,20 & 4,15 \\
\hline 2011 & 42,17 & 13,49 & 11,5 & 12,65 & 4,01 & 1,2 & 2,42 & 4,36 \\
\hline 2012 & 15,85 & 5,39 & 13,12 & 11,68 & 5,28 & 4,38 & 2,31 & 3,14 \\
\hline 2013 & 0,67 & 0,2 & 1,33 & 4,66 & 0,7 & 0,28 & 0,9 & 2,03 \\
\hline 2014 & 0,90 & 0,55 & 2,43 & 5,67 & 1,4 & 2,08 & 1,11 & 3,53 \\
\hline Average annual rate & 12,16 & 4,06 & 6,01 & 7,29 & 2,77 & 1,82 & 1,79 & 3,44 \\
\hline
\end{tabular}

Note: $0+-$ yearlings, $1+-$ biennial; $\mathrm{x}$ - quantity, ind./100m $; . \mathrm{y}-$ biomass, ind. $/ 100 \mathrm{~m}^{2}$.

The greatest quantity of two-year pipefish in the Zaporozhian Reservoir was recorded in 2011 and amounted to $2.42 \mathrm{ind} . / 100 \mathrm{~m}^{2}$ of shallow waters, the smallest number $-0.9 \mathrm{ind} . / 100 \mathrm{~m}^{2}$ in 2013. Biomass of two-year pipefish ranged from $2.03 \mathrm{~g} / 100 \mathrm{~m}^{2}$ (index 2013) to $4.36 \mathrm{~g} / 100 \mathrm{~m}^{2}$ (index 2011). The average annual quantity and biomass two-year pipefish in the Zaporozhian Reservoir was 1.79 ind. $/ 100 \mathrm{~m}^{2}$ and $3.44 \mathrm{~g} / 100 \mathrm{~m}^{2}$ respectively.

Black-striped pipefish is the dominant species in littoral zone of Samara Bay of the Zaporozhian Reservoir. Forasmuch as pipefish is an euryhaline species, it can live in both fresh and salt waters. Mostly this fish could be found in thickets of water plants. Freshwater form leads settled life in lakes, reservoirs and oxbow lakes, almost without making long migrations. Because of the increased salinity of Samara Bay, the rate of which in some years can reach about $2000 \mathrm{mg} / 1$ (2 g/l) pipefish significantly extended the range of its habitat in the bay and along with other fish species 
of Ponto-Caspian marine faunal complex has increased population in this region of Zaporozhian Reservoir.

Researches of 2010-2014, showed that the greatest quantity of pipefish in the Samara bay was observed in 2011 and amounted to 41.17 ind./100 $\mathrm{m}^{2}$ of shallow reservoir areas. Biomass of pipefish fingerlings ranged from $0.2 \mathrm{~g} / 100 \mathrm{~m}^{2}$ (index 2013) to $13.49 \mathrm{~g} / 100 \mathrm{~m}^{2}$ (index 2011). The average annual quantity and biomass of pipefish fingerlings in the Samara bay reached 12.16 ind. $/ 100 \mathrm{~m}^{2}$ and $4.06 \mathrm{~g} / 100 \mathrm{~m}^{2}$, respectively (Table 1 ).

Considering the long-term indicators of quantity and biomass of pipefish in investigated areas, it was found that the quantity of pipefish fingerlings in Samara Bay is almost 4.5 times higher than it is in the Zaporozhian Reservoir and annual average biomass of pipefish fingerlings in littoral areas of Samara Bay near 2.2 times higher than it is in Zaporozhye reservoir. According to annual average of quantity of two-year black-striped pipefish is 3.3 times higher in the Samara Bay than in the reservoir, and annual average of biomass of two-year pipefish in the shallow waters of the bay is 2 times higher than in the Zaporozhian Reservoir.

An analysis of quantity and biomass research indicates decrease in the number of pipefish in juvenile fish seines catches in 2013 and 2014, but in our opinion it is not alarming, because the coastal areas of Zaporozhian Reservoir and small rivers in Dnipropetrovsk region considerably overgrown with aquatic vegetation, which creates negative conditions for fry catches. Therefore, in our opinion, the number of pipefish in the waters of Dnipropetrovsk region remained stable, and a significant fluctuation of annual figures is caused by difficulties of field studies of water bodies due to a significant overgrowth and eutrophication of coastal areas.

Research of pipefish reproduction has a great theoretical and practical importance for solving problems of the spread of this species and adaption to new conditions of existence. A further aspect of the study of the reproductive system of pipefish is the study of the histological features of the development of sexual products and phases of development of the gonads in conditions of Zaporozhian Reservoir.

\section{CONCLUSIONS}

In Zaporozhian Reservoir pipefish is widespread and lives in the open part of the reservoir, and in the thickets of aquatic plants.

In the spectrum of the nutrition of the black-striped pipefish marked the following feed elements: rotifers (Bosmina sp., Chydorus sp.), small planktonic crustaceans (Daphnia sp., Cyclops $s p$., Chydorus sp.), cianobacterium (Cyanophyta) and detritus.

In Zaporozhian Reservoir conditions spawning of pipefish is at a water temperature 18,0$22,0{ }^{\circ} \mathrm{C}$ in the coastal part of the reservoir at a depth of 0.4 to $1.3 \mathrm{~m}$. Spawning of females is batched - eggs are laid in several portions, the male takes care of the offspring. It was found that the male pipefish is hatching eggs from several females. Fertility of pipefish ranges from 26 to 65 eggs. Measurements of eggs are 1,2 $\pm 0,05 \mathrm{~mm}$. In the male brood chamber on the third day after spawning eggs reached $1,4 \pm 0,24 \mathrm{~mm}$. The number of free embryos in the brood chamber of males ranged from 35 to 72 pieces. Formed whitebaits reach $1-1.5 \mathrm{~mm}$ long.

During the study period, the highest quantity of pipefish in the Zaporozhian Reservoir was recorded in 2012 and amounted to 5.28 ind./100 $\mathrm{m}^{2}$ of shallow reservoir areas. Biomass of fingerlings ranged from $0.28 \mathrm{~g} / 100 \mathrm{~m}^{2}$ to $4.38 \mathrm{~g} / 100 \mathrm{~m}^{2}$. The number of two-year pipefish in the Zaporozhian Reservoir is in the range from 0.9 ind. $/ 100 \mathrm{~m}^{2}$ to $2.42 \mathrm{ind} . / 100 \mathrm{~m}^{2}$ of shallow reservoir areas. Biomass of two-year pipefish ranged from $2.03 \mathrm{~g} / 100 \mathrm{~m}^{2}$ to $4.36 \mathrm{~g} / 100 \mathrm{~m}^{2}$.

Due to the high mineralization of Samara Bay water, pipefish significantly extended the range of its habitat at this area of the reservoir. In the Samara bay quantity of pipefish fingerlings was 4.5 times higher than in the Zaporozhian Reservoir, and the average rate of the biomass of pipefish fingerlings in littoral areas of the bay is 2.2 times higher than in the Zaporozhian Reservoir. The number of two-year pipefish in the Samara Bay is 3.3 times higher than in the reservoir, and annual average biomass of two-year pipefish in the shallow waters of the bay is 2 times higher than in the Zaporozhian Reservoir. 


\section{References}

[1] J.P. Quignard Les caracteristiques biologiques et environnementales des lagunes en tant que base biologique de l'amenagement des pecheries. FAO - GFCM Etudes et Revues 61 (1), 1984. 338 .

[2] I. Ferrari, A.R Chieregato Feeding habits of juvenile stages of Sparus auratus L., Dicentrarchus labrax L. And Mugilidae in a brackish embayment of the Po River Delta. Aquaculture 25 (1981): $243-257$.

[3] I. Ferrari, R. Rossi Regime alimentare di Atherina boyeri Risso in una laguna Delta del Po. Nova Thalassia 6 (1983): 275-280

[4] P. Cakic, M. Lenhardt, D. Mickovic, N. Sekulic, \& L. J Budakov Biometric analysis of Syngnathus abaster populations. Journal of Fish Biology, 60 (2002): 1562-1569.

[5] N. A. Kiryukhina Morphological variability in black-striped pipefish Syngnathus nigrolineatus in relation to its invasion into the Volga basin reservoirs. Russian Journal of Biological Invasions, 2013, Vol. 4, No 3, pp. 149-155.

[6] C. E. Dawson Syngnathidae. In: Fishes of the North-eastern Atlantic and the Mediterranean (Eds. Whitehead, P. J. P., Bauchot, M. L., Hureau, J. C., Nielsen, J. \& Tortonese, E.) (1986): pp. 628-639. Unesco.

[7] D.S. Khristenko, N.Y. Rudik-Leuska, G.O. Kotovska Atlas of adventive fish fauna of the Dnipro Basin. Monograph. Kyiv: Fitosotsiotsentr, 2011, pp. 67-68.

[8] M. Campolmi, P. Franzoi, \& A. Mazzola Observations on pipefish (Syngnathidae) biology in the Stagnone lagoon (west Sicily). Publicaciones Especialies Instituto Espanol Oceanografia, 21 (1996): 20-209.

[9] J. A. Tomasini, J. P. Quignard, C. Capapé \& J. L. Bouchereau Facteurs du succés reproductif de Syngnathus abaster Risso, 1826 (Pisces, Teleostei, Syngnathidae) en milieu lagunaire mediterranéen (lagune de Mauguio, France). Acta Oecologica, 12 (1991): 331-355.

[10] F. Riccato, R. Fiorin, A. Franco, P. Franzoi, A. Libertini, F. Pranovi \& P. Torricelli Population structure and reproduction of three pipefish species (Teleostei, Syngnathidae) in a seagrass meadow of the Venice Lagoon. Biologia Marina Mediterrânea, 10 (2003): 138-145.

[11] Biological diversity in Ukraine. Dnipropetrovsk region. Cyclostomes (Cyclostomata). Fish (Pisces). Under the general. Ed. prof. A.E. Pakhomov. Dnepropetrovsk: Dnepropetr. University Press, 2008.

[12] A.F. Koblitskaya The determinant of freshwater fish juvenile [2nd ed., Revised. and add.]. Moscow: Light. and vehi. prom-st, 1981.

[13] A.P. Petlina, V.I. Romanov A study of freshwater fish juvenile in Siberia. Tomsk: Publishing house of Tomsk University Press, 2004.

[14] Guidelines for the Use of Fishes in Research (2004) American Fisheries Society (AFS). 57.

[15] D.J. Semenov, V.V. Shestakov, A.I. Maslennikov Bioecological characteristic of black-striped pipefish (Syngnathus nigrolineatus Eichwald, 1831) of the Kuibyshev Reservoir. South Russia: Ecology and development. Number 4, 2008. 141-145.

[16] G.S. Stromenko, O.M. Marenkov Reproduction of black-striped pipefish (Syngnathus abaster nigrolineatus Eichwald, 1831) in Zaporizhia reservoir Abstracts Conference of young researchers, zoologists - 2015 (Kyiv, Institute of Zoology of the National Academy of Sciences of Ukraine, 1819.11 2015). Kyiv, 2015. 34.

[17] Carina Santos da Silva Reproductive Ecology of the mildly sex-role reversed pipefish, Syngnathus abaster. Doutoramento em Biologia. Universidade do Porto (2008): 44. 